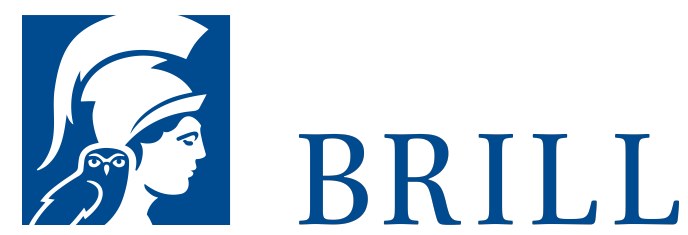

\title{
Moral und Gottesbild
}

Aufsätze zur konkreten Ethik 1996--2012

Author: Ludwig Siep

Die Aufsätze dieses Bandes zeichnen den Weg der neuzeitlichen Philosophie zu einer autonomen Ethik nach, die von religiösen Lehren und naturalistischen Annahmen der Wissenschaft gleichermaßen unabhängig ist. Diese Ethik bedarf aber der Erneuerung von Wertbegriffen der Natur, wenn sie Kriterien für die technische Naturbeherrschung und den richtigen Umgang mit dem menschlichen Körper entwickeln will. Die Aufsätze prüfen, wie weit die philosophische Ethik von den Begriffen der antiken Philosophie (kosmos, physis) und der christlichen Tradition (Schöpfung, Versöhnung) noch lernen kann. Aus einer Erneuerung dieser Begriffe, die mit den modernen Biowissenschaften zusammenpasst, werden Stellungnahmen zu biotechnischen und medizintechnischen Problemen entwickelt. Dabei geht es vor allem um die Technisierung der lebendigen Natur, die Verbesserung des Menschen und die technischen Optionen am Beginn und Ende des menschlichen Lebens.

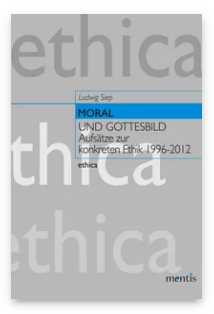

Pages: 420

Seiten

Language:

German

Subjects:

General,

Philosophy

Publisher: Brill | mentis

Series:

ethica, Volume:

24

E-Book (PDF)

Released online: o1 Apr 2013

ISBN: $978-3-$

$89785-867-1$

List price

Paperback

Publication date: o1 Apr 2013

ISBN: 978-3-

89785-321-8

List price 
For more information see brill.com

Order information: Order online at brill.com +44330 333 0049 | customerservices@brill.com Submission information: brill.com/authors

Titles published by Brill | Fink, Brill | mentis or Brill | Schöningh: +49(o)715413279216| brill@brocom.de 